\title{
Populist leaders and political parties
}

\author{
N. W. Barber*
}

(Received 17 December 2018; accepted 20 January 2019)

\begin{abstract}
Populism is a particular type of constitutional pathology; a brand of groupthink in which a leader establishes a direct connection with the people and, by virtue of this connection, is able to govern outside the established constitutional processes of the state. This Article reflects on the interaction between populism and political parties. It argues that one of the roles of political parties is to act as a medium between political elites and the people; a medium that can, or should, enable the people to exercise control over this elite through their membership of parties. Populism therefore presents a threat to the proper operation of political parties, and the proper operation of political parties correspondingly threatens populism.

This Article begins by reflecting on the nature of populism. It does not pretend to provide a complete account of that phenomenon, but rather aspires to identify one strand of populist rule: A particular type of connection between the leader and her people. Second, the paper reflects on the constitutional role of political parties. Whilst political parties have often been treated critically in British constitutional scholarship, it will be argued that they are essential to the success of the democratic process: Modern representative democracy cannot function in their absence. Finally, these two sections of the paper will be drawn together: One explanation for the rise of populism is the weakness of political parties, and one way of combating, or mitigating, populism is for the state, and the citizenry, to support and facilitate parties. This Article suggests a correlation between the decline of political parties and the rise of populism, but it cautiously avoids making claims of causation. It could be that the decline of political parties leads to the rise of populism, as voters who are faced with a choice of superannuated parties turn, instead, to charismatic individuals. Or it could be that the rise of populism leads to the decline of political parties, as voters develop a direct relationship with leaders and, as a result, cease to engage with each other within the context of parties. Or, perhaps, these interactions might occur together, forming a feedback loop, with the decline of parties leading to the rise of populism which, in turn, hastens party decay.
\end{abstract}

Keywords: representative democracy; political parties; populism; constitutional pathology

\section{A. Populism as groupthink}

Populism is an idea that is in fashion, and, like many fashionable ideas in constitutional theory, has been given a wide range of different-even contradictory-meanings. To an extent, this disagreement is not problematic. Populism, in common usage, is a very broad term. In academic writings, different writers use the word to pick out different features of our political world and, providing that they are clear about how the term is being used, there is little to be gained in arguing over the "true" meaning. In this Article, I assume that populism is a negative feature

${ }^{*}$ N.W. Barber is a professor of Constitutional Law and Theory, Trinity College, Oxford. Thanks are due to Andrea Pin, Ewan Smith, Leah Trueblood, and Julius Yam. Email: nick.barber@trinity.ox.ac.uk

(c) 2019 The Author. Published by Cambridge University Press on behalf of the German Law Journal. This is an Open Access article, distributed under the terms of the Creative Commons Attribution-NonCommercial-NoDerivatives licence (http://creativecommons.org/licenses/by-nc$\mathrm{nd} / 4.0 /$ ), which permits non-commercial re-use, distribution, and reproduction in any medium, provided the original work is unaltered and is properly cited. The written permission of Cambridge University Press must be obtained for commercial re-use or in order to create a derivative work. 
of government, a term of criticism rather than a term of praise. ${ }^{1}$ It is, though, not a criticism of the substantive policies of a government. It is tempting to claim that policies we dislike are "populist"; to claim, for instance, that policies such as Brexit, the restriction of immigration, or constitutional reforms that limit the latitude of the courts, are distinctively populist policies. The suggestion is not only that these policies are substantively misjudged, but that they are also constitutionally flawed. But, wise or not, all of these policies are ones that a reasonably well-functioning constitutional order could produce. Populism, in contrast, is a critique of how these decisions have been made, an accusation that the proper mechanisms of constitutional government have been subverted. But not all forms of subversion are populist. Populism can be distinguished from other types of constitutional dysfunction. Populists are not tyrants or dictators, though, as populism develops, they might slide into these forms of state. Tyrants and dictators rule without the support of the bulk of the people, using fear and coercion as primary tools of government. Populists, in contrast, rely on the support of the people for their power - though, like all rulers, they buttress this support with coercion against some state members. Whilst we should doubt the claim commonly made by populists that they speak for the people as a whole, populists, as opposed to tyrants, succeed in securing the support of a sizable part of the people. Perhaps as a corollary of this, democratic structures of control continue to exist in the populist state, though in an attenuated form. Populists subvert constitutional government, but do so in a manner that brings much of the people along with them, and which allows - and requires - the basic structures of a democratic state to remain in place.

The primary feature of populism is the existence of a leader who claims to have-and to a significant extent is able to make good on the claim to have-a direct, unmediated, connection with the people of the state. Vladimir Putin in Russia and Recep Tayyip Erdogan in Turkey are two contemporary leaders who broadly fit this model. ${ }^{2}$ This aspect of populism is at the core of Kurt Weyland's work on the topic. ${ }^{3}$ The populist leader presents herself as the voice of the people and is, through the support the people accord her, able to govern outside existing constitutional structures or is able to dominate those structures, turning them into little more than rubber-stamps for her decisions. Jan-Werner Müller, in his recent book What is Populism? draws attention to this feature of populism. Müller chronicles the ways in which populist leaders create what he calls an aesthetic of "proximity to the people." 4 So, for example, some populist leaders make use of the media to communicate directly with their people, appearing on phone-in shows where callers can raise questions with the leader and, at times, making decisions in response to these calls. To give an extreme example, Müller recounts an incident in which Hugo Chávez ordered the deployment of tanks during one of these broadcasts. ${ }^{5}$ The import of such exercises is twofold. The populist leader shows herself to have a direct connection to the people, listening to their concerns, and, in addition, is able to respond to these concerns without having to negotiate the decision through constitutional structures. As Müller notes, there are echoes of Rousseau's conception of democracy in the way in which populist leaders present themselves to their people. ${ }^{6}$

\footnotetext{
${ }^{1}$ Others have given the term a positive spin. Chantal Mouffe, for instance, takes populism to mean a political movement that champions the 'underdog': Chantal Mouffe, For A Left Populism 10-11 (2018); see also Madeleine Albright, Fascism: A WARning 226-29 (Harper Collins 2018). Though see the critique of this approach in: Alan L. Bogg \& Mark R. Freedland, Max Planck Institute for Comparative Public Law \& International Law (MPIL) Research Paper Series: Labour Law in the Age of Populism: Towards Sustainable Democratic Engagement, Res. Paper No. 2018-15 MPIL 4-6 (2018).

${ }^{2}$ See Ihsan Yilmaz \& Galib Bashirov, The AKP After 15 Years: Emergence of Erdoganism in Turkey, 39 THIRD WORLD Q. 1812, 1813-15, 1820-21 (2018) (discussing the rise of Recep Erdogan in Turkey). See generally M. Steven Fish et al., What is Putinism?, 28 J. Democracy 61 (2017).

${ }^{3}$ See generally Kurt Weyland, The Oxford Handbook of Populism: Populism: A Political-Strategic Approach (Cristobal R. Kaltwasser et al. eds., 2017).

${ }^{4}$ Jan-Werner MÜller, What is Populism? 43 (2017).

${ }^{5}$ See id.

${ }^{6}$ See MÜller, supra note 4 , at 25-32.
} 
Following Rousseau, the populist leader asserts that there exists a general will within the people and, moreover, that she has a special capacity to identify and articulate that general will. Impediments to the vindication of this general will are, then, impediments to the operation of democracy. The populist leader-in contrast to the tyrant-invokes democratic values to legitimate her decisions and the circumnavigation of constitutional processes in the execution of these decisions.

Alongside this primary characteristic of populism, there are a number of secondary characteristics features that need not be present for a system to be identified as populist, but which often accompany the populist style of government. These secondary characteristics include the division of members of the state between insiders and outsiders; the tone in which populists conduct political discourse; and, finally, an attack on those structures of the constitution that limit the power of the populist.

Populist leaders frequently distinguish between the "real" people and other groups within the state. ${ }^{7}$ One of the many problems with Rousseau's account of the general will is its patent artificiality: This supposed general will simply does not exist outside of the institutions and constitutional structures that make the decisions of the state. There is plenty of good-faith disagreement within the political community-over both ends and means - that cannot be resolved by discussion, though the debate may be concluded by a vote. After the vote, we can talk of the state having decided - it is plausible, perhaps, to talk of a "general will" in this sense-but those who were engaged in the debate need not have altered their opinion, nor even have accepted the process of voting, as a legitimate way to end the debate. One of the ways the problem of disagreement is mitigated in Rousseau's work is by the exclusion of those who do not acquiesce to the process of decision-making, those who have declined to sign up to the social contract; these individuals are to be regarded as foreigners within the territory of the state. ${ }^{8}$ As such, they can presumably be compelled to comply with the demands of the state, but will not take part in forming the general will and, perhaps, will not be shown the same level of concern as state-members. Populist leaders often make a similar move, splitting state membership between those within and those outside the people. Sometimes populists identify these others as elite groups-folk who presently have control over the state and who are thwarting the will of the people. On other occasions, these others may comprise groups of state-members who supposedly act against the people's interests-perhaps identifiable minority groups within the state. These people may be state-members as a matter of form, legally identified as citizens, but they are not truly part of the people as identified by the populist. In each case, the failures of the state are attributed to these groups; these are the groups that have prevented the realization of the will of the people and, as a result, have stopped the state from functioning successfully. By excluding these state-members from the category of "the people," the populist leader's claim to speak for that group is made more plausible.

Second, populist leaders tend to speak directly to the people, using language that has a broad appeal. Pierre Ostiguy styles this as "flaunting the low." Glossing this, we might say that populists often speak in highly emotional language and are impatient with reasoned arguments. Frequently, the discourse of populism is framed in existential terms that seek to inspire fear and panic: The state faces a disaster that only the populist leader, through rapid, and sometimes unconstitutional action, can avert. ${ }^{10}$ Rather than provide evidenced arguments for these positions, populists seek to

\footnotetext{
${ }^{7}$ See generally Cas Mudde, The Oxford Handbook of Populism: Populism: An Ideational Approach (Cristobal R. Kaltwasser et al. eds., 2017); see also MülLER, supra note 4, at 23.

${ }^{8}$ See Jean-Jacques Rousseau, The Social Contract and Other later Political Writings 124 (Victor Gourevitch ed., 1997).

${ }^{9}$ See Pierre Ostiguy, The Oxford Handbook of Populism: Populism: A Socio-Cultural Approach 74 (Cristobal R. Kaltwasser et al. eds., 2017); see also Benjamin Moffitt \& Simon Tormey, Rethinking Populism: Politics, Mediatisation and Political Style, 62 Pol. STUD. 381, 391-94 (2014).

${ }^{10}$ See Moffitt \& Tormey, supra note 9, at 391-92; see also Cas Mudde, The Oxford Handbook of Populism: Populism: An IdeAtional Approach 63-64 (Cristobal R. Kaltwasser et al. eds., 2017).
} 
make an emotional connection with the people, using visceral language that circumvents the structures and disciplines of reasoned decision-making. It is little surprise that Donald Trump, a would-be populist leader, has continued to use his Twitter account even after becoming President of the United State of America.

Finally, populist leaders often use their hold on power to reduce the efficacy of constitutional structures, acting to weaken those institutions within the state that might limit their capacity to rule. ${ }^{11}$ Opposition parties may find their capacity to dispute proposed laws within the legislature reduced, or might find themselves excluded from deliberations over constitutional change. ${ }^{12}$ Courts might find their capacity to challenge executive decisions limited, or their composition altered, so that judges are more amenable to the wishes of the populist leader. ${ }^{13}$ It is worth noting, though, that there are limits to the extent to which populists can subvert constitutional structures before sliding into a dictatorship, a different form of constitutional dysfunction. Populism is a perversion of democracy rather than a refutation of it. The populist leader claims the support of the electorate and enjoys, to some significant degree, the support of a portion of that body. Whilst the subversion of constitutional structures may be a feature of populism, their maintenance, in some form, is also a feature of this form of rule. ${ }^{14}$ The populist needs a form of constitutional validation that only constitutional structures can give. The populist leader needs to win, or at least make a plausible claim to have won, elections, and needs the endorsement of the judges, even if she stacks the court to obtain this endorsement. In short, the populist claims legitimacy under the pre-existing constitutional structures. A dictator, in contrast, could abandon elections entirely and stop the courts from ruling on her decisions, removing, rather than subverting, the constitutional processes.

The account of populism developed in this section has presented it as a version of groupthink. Groupthink is a phenomenon identified by the psychologist Irving Janis. ${ }^{15}$ It arises where a decision-making group develops rules that stifle, rather than permit, dissent. Instead of considering the merits of a course of action, the group exerts its energies defending the decision it has reached and attacking its critics; the group closes in upon itself. ${ }^{16}$ In populism, decision-making is focused on a single person, the leader, with those around her playing only a supporting role. It is the leader who has the direct connection with the people; others in government are tasked with carrying out the leader's commands or communicating her decisions; it is not their job to express dissent or to seek to alter the leader's mind.

If we turn to the psychological literature on group dysfunction that pre-dates, and perhaps helped shape Janis' account of groupthink, populism is strongly reminiscent of W. R. Bion's work on social groups and the various problems that might befall them. ${ }^{17}$ One of the dysfunctions Bion identified arises when the group comes to believe that its leader is uniquely able to provide for the needs of the group. ${ }^{18}$ The group then starts to mimic the behavior of a child, placing total reliance

\footnotetext{
${ }^{11}$ See MülLER, supra note 4, at 60-68. See generally Kim L. Scheppele, Autocratic Legalism, 85 U. CHI. L. ReV. 544 (2018). See also David Landau, Populist Constitutions, 85 UnIV. OF CHI. L. Rev 521, 526-29 (2018).

${ }^{12}$ See generally Renata Uitz, Can You Tell When an Illiberal Democracy Is in the Making? An Appeal to Comparative Constitutional Scholarship from Hungary, 13 INT'L J. Const. L. 279 (2015). See generally Emilia Palonen, Performing the Nation: The Janus-Faced Populist Foundations of Illiberalism in Hungary, 26 J. ConTEMP. EUR. STUD. 308 (2018).

${ }^{13}$ See generally Wojciech Sadurski, University of Sydney Law School Legal Studies Research Paper Series: How Democracy Dies (in Poland): A Case-Study of Anti-Constitutional Populist Backsliding, Res. Paper No. 18/01 Sydney L. SCH. RPS SUBMITTER (2018), https:/ssrn.com/abstract=3103491.

${ }^{14}$ See Landau, supra note 11, at 537-41; see also David Landau, Abusive Constitutionalism, 47 U. CAL. DAVIS L. REv. 189, 211-16 (2013).

${ }^{15}$ See generally Irving L. Janis, Groupthink (2nd ed., 1982); see also Cass R. Sunstein, Why Societies NeEd Dissent 140-44 (2003).

${ }^{16}$ See JANIS, supra note 15 , at 245-48.

${ }^{17}$ See generally W. R. BION, EXPERIENCEs IN Groups AND Other PAPERs (1989); see also N. W. BARBER, THE Constitutional State 104-23 (2010).

${ }^{18}$ See Bion, supra note 17 , at $78-86$.
} 
on, and trust in, its parent. Although this type of relationship is appropriate for a child, in an adult it constitutes a lack of maturity, amounting to a pathological failure to take control and accept personal responsibility. ${ }^{19}$ A group entering this position acts like an immature adult. It avoids engaging with the problems that face it by placing blind trust in the leader, shunning difficult decisions and internal debate. Discussion within the group ceases as members of the group stop functioning collectively and attempt to form direct personal relations with the leader. ${ }^{20}$ Members become united by a common allegiance, rather than by a shared commitment to work together as a team; the group dynamic becomes vertical rather than horizontal. This sort of group dysfunction can be seen particularly clearly in cults where the leader is accorded a position of authority that rests on her supposedly unique capacity to identify and advance the interests of the cult's members. ${ }^{21}$ Interestingly, as Anthony Pratkanis and Elliot Aronson have shown, a characteristic feature of cult leadership is that the leader often acts contrary to the cult's rules; the very rules to which she insists members adhere. The cult leader both emphasizes the importance of these rules and shows her strength by circumventing them. ${ }^{22}$ Cult leaders do not simply govern through force - by threatening backsliders with punishment —instead, they gain power through cultivated uncertainty. Those in the cult cannot know what conduct will be punished at any given time. Simply following the ostensible rules of the cult will not be enough to protect the cult member. Instead, she must be slavishly loyal to the leader; her only source of safety is to keep on the right side of this individual. ${ }^{23}$ The authority of the cult leader is established by the rules of the group, yet her broader power rests, in part, on her capacity to transcend many of those rules and exert power outside of the normal group structures.

Returning to the state, where the dysfunction Bion identifies arises, the leader of the state comes to be regarded almost as a messianic figure. ${ }^{24}$ The political connection now rests on emotion, rather than rationality. Attempts to challenge the leader with rational argument amount to a rejection of the emotional bond that has, in the populist state, become a test of group membership; to be one of the people is to have faith in the leader. ${ }^{25}$ In addition, the political connection is now personal rather than communal, vertical not horizontal. Citizens within the populist state have a direct relationship with the leader, rather than being part of a structure through which the leader is chosen and acts. In a populist state, the state still acts, or purports to act, for its people, but the people no longer govern collectively. Instead, they have entrusted government to a single figure: The leader. There is a loss of intermediate structures, those institutions within which people interact and which, in turn, interact with the state. This Article focuses on political parties, but populism is frequently opposed to other parts of civil society that play a similar role-universities, trade unions, or even large corporations. ${ }^{26}$ Populism amounts to government by faith, and government by faith is unlikely to end well: As Aristotle wrote, millennia ago, if we could identify

\footnotetext{
${ }^{19}$ Compare Alexandra Stein's account of indoctrination in cults: AleXANDra STeIn, Terror, Love \& Brainwashing: AtTachment in Cults and Totalitarian Systems 43-62 (2017).

${ }^{20}$ See BION, supra note 17 , at 119.

${ }^{21}$ See Anthony Pratkanis \& Elliot Aronson, Age of Propaganda: The Everyday Use and Abuse of Persuasion 302-17 (rev. ed., 2001); see also Robert S. BARON ET AL., LEADERSHIP AND PoWER: IdENTITy ProcesSES IN GROUPS AND Organizations 182 (Daan van Knippenberg \& Michael A. Hogg eds., 2003).

${ }^{22}$ See PratKanis \& Aronson, supra note 21, at 306. There is more than an echo here of Carl Schmitt's conception of a sovereign as an entity (or, more likely a person) who can act outside of the legal order: Carl Schmitt, Political Theology: Four Chapters on the Concept of Sovereignty 5, 15 (George Schwab trans., 2006); BARBER, supra note 17, at 121-23; N. W. BARBER, The Principles of Constitutionalism 28-29, 128-29 (2018).

${ }^{23}$ See STEIN, supra note 19 , at 109-11.

${ }^{24}$ See BION, supra note 17 , at 84 ; see also BARON ET AL., supra note 21 , at 170-73.

${ }^{25}$ Another point of comparison with cults: PRATKANIS \& ARONSON, supra note 21, at 307-311; see also STEIN, supra note 19, at $108-26,132-35$.

${ }^{26}$ See generally BOGG \& FREEDLAND, supra note 1; see also BARBER, supra note 22, at 121-46; Yet again, a comparison with cults can be drawn: STEIN, supra note 19, at 63-107.
} 
those with the capacity to govern as well as the gods, we should appoint them king, but finding those worthy of kingship has long proved an impossible task. ${ }^{27}$

The model of populism presented in this section should be thought of as an ideal-type; one which seeks to extract and draw together important features of real-world polities. But populism is also a matter of degree; states can be more or less characterized by populism. Indeed, it is likely that most, perhaps all, democratic leaders have some populist characteristics. Any sensible politician running for office will seek to appeal to people's emotions. Many will hope to convince the electorate that it is they, rather than their opponents, who truly speak for the people; most will seek to build a personal connection with voters. When the constitution is functioning well, those who succeed in the electoral process find that their capacity to act is constrained within constitutional structures that compel them to discuss and compromise with others. The leader's personal connection with the electorate then becomes one source of her political capital; capital that is then used to facilitate their engagement within the constitutional order. On occasion, even in normally well-functioning constitutions, a leader may be able to use this political capital to by-pass these normal constitutional structures and to avoid the discussion and negotiation normally required before action. Here, the pathology of populism can arise within an otherwise non-populist system. ${ }^{28}$

\section{B. Political parties against populism}

Political parties tend to receive a critical treatment in constitutional scholarship. ${ }^{29}$ The claim that political parties are a blight on the democratic process is a recurrent one-indeed, it is an argument that seems to resurface in British constitutional scholarship at regular forty-year intervals. ${ }^{30}$ The broad thrust of this critique is that political parties hamper democracy by pressuring representatives into adopting positions that they would otherwise have rejected. The legislature ceases to be a forum in which views and opinions are freely offered and contested and becomes a venue in which groups seek to gain power within the chamber and posture to gain approval outside of its walls. Discussion outside of these groups is silenced rather than encouraged. When presented in this way, parties appear ethically unattractive, encouraging representatives to trade their integrity for a chance of political power. Despite these worries, political parties are stubbornly vibrant, a significant feature of all successful democratic states. It will be argued in this section that the apparent vices of political parties are in fact virtues and that we should understand representative democracy as a team game, with all the disciplines and constraints that flow from that mode of composition. It will be argued that political parties are a necessary feature of a functioning democratic system, and if they did not exist the principle of democracy would require the state to encourage and support their emergence. The first part of this section identifies the constitutional roles that political parties play within a well-functioning constitution. The second part turns to populism and argues that some of the features of political parties are antithetical to this form of leadership.

\section{The constitutional role of political parties}

It could be that political parties, in their modern form, emerged because they were necessary for the functioning of a representative democracy within a mass electorate. They create structures that

\footnotetext{
${ }^{27}$ See Aristotle, The Politics and the Constitution of Athens VII.14, 1332b16-23 (Stephen Everson ed., 1996).

${ }^{28}$ See Archie Brown, The Myth of the Strong Leader: Political Leadership in the Modern Age 326-41 (2014).

${ }^{29}$ Some of the following paragraphs are taken from N. W. BARber, The PrinCiPles of Constitutionalism 147-86 (2018).

${ }^{30}$ See generally Hilaire Belloc \& Cecil Chesterton, The Party System (1911); see also G. W. Keeton, The Passing of Parliament ch. 5 (1952); Adam Tomkins, Our Republican Constitution 115-39 (2005); Nancy L. Rosenblum, On the Side of the Angels: An Appreciation of Parties And Partisanship 165-209 (Princeton Univ. Press 2008).
} 
enable the legislature to control the executive whilst also being able to engage with the electorate. With these thoughts in mind, political parties play at least four important roles within the state.

First, they provide structures within which people with broadly similar views can discuss political issues and work together to produce coherent policy platforms. ${ }^{31}$ This process of discussion may help refine and improve policies, but it also permits the creation of wider coherence across policies. ${ }^{32}$ It is unlikely that a member of a political party will have informed views about the whole range of state activities, from healthcare to defense, from education to international aid. Working with others allows a party member to be part of a process that produces a complete policy platform, one which ranges across the whole spread of government. ${ }^{33}$

Second, and relatedly, parties permit the democratic control of the administration. ${ }^{34}$ They enable the democratic side of the constitution to produce a set of people who can supervise the administrative branch, putting into effect the decisions of the legislature. ${ }^{35}$ In parliamentary systems, the formulation of these governing teams is done in the legislature. The government is drawn from the party, or parties, that encompass the largest number of representatives in the chamber. In presidential systems, parties select and put forward candidates who, once elected, assemble cabinets which consist of people who are normally sympathetic to, or drawn from, their party. In each case, the party plays two roles. It selects the person who will be leader-the prime minister or president-and then creates structures through which that leader can, with more or less latitude, select the governing team. There is a curious asymmetry between parliamentary and presidential systems in terms of the relative power of the leader and the power of the party. In parliamentary systems, the prime minister remains heavily dependent on the party throughout her time in office. She can lose her post at any time if she loses the support of her supporters in the chamber. In contrast, in presidential systems, after an election the direct power of the party over the President is very limited. Setting aside impeachment, the party cannot remove a president it comes to dislike. The weakness of the party is especially notable when the president does not want, or cannot have, another term. In this case, the president no longer needs the party's support in future elections. It does not follow, however, that weaker party control equates to a stronger leader. A prime minister who is supported by her party-or, put another way, is acting in a manner which the party approves - has very considerable power. She is able to push legislation though the legislature and is able to effect significant changes to state policy. A president who is not supported by her party may remain secure in office, but can achieve very little, with the legislature blocking her measures. In either case, a leader who wishes to accomplish change needs the continued backing of her party. In both presidential and parliamentary systems, the party acts as a link between the executive and the legislature.

Third, a party system is necessary for the operation of elections within the state. ${ }^{36}$ Modern states are far too large - and even ancient states would have been too large, if all those who were morally entitled to vote had enjoyed the franchise - for voters to know the candidates who stand for election well enough to pass judgment on their characters and views. ${ }^{37}$ Parties, and the

\footnotetext{
${ }^{31}$ This observation lay at the heart of Burke's defence of political parties: JESSE Norman, Edmund Burke: THE FIRsT Conservative 215-36 (2013), see also Jonathan White \& Lea Ypi, On Partisan Political Justification, 105 Am. Pol. SCI. Rev. 381, 387-89 (2011); Richard Bellamy, Political Constitutionalism 232 (2007).

${ }^{32}$ See Nancy L. Rosenblum, On the Side of the Angels: An Appreciation of Parties and Partisanship 306-11, 356-62 (2008); see also Samuel P. Huntington, Political Order in Changing Societies 91 (1968).

${ }^{33}$ It could be the presence of political parties that enables legislatures to minimise the dangers of cycling: DANIEL A.P. Farber \& Philip P. Frickey, Law and Public Choice: A Critical Introduction 48-52 (1991).

${ }^{34}$ See Huntington, supra note 32, at 405.

${ }^{35} \mathrm{See}$ John S. Mill, On Liberty and Other Essays: On Representative Government 271-78 (John Gray ed., 1991).

${ }^{36}$ See Russell J. Dalton et al., Political Parties and Democratic Linkage: How Political Parties Organize DEMOCRACY 81-141 (2011).

${ }^{37}$ It could be that a focus on the operation of small city states has distorted our understanding of the functioning of democracy to the detriment of political parties: RoBert A. DAHL, DEMOCRACY AND ITS CRITICS 13-23 (1989).
} 
leadership of these parties, stand as substitutes for these candidates. Voters make their selection on the basis of national campaigns and their assessment of the probable effectiveness of the party leadership. Indeed, given the last two functions of political parties, discussed in the previous paragraphs, such an assessment might be more rational than attempting to make a judgment on the merits of the individuals facing election. It will be the party as a whole that determines policy and selects the people who will occupy positions of power. The role of the individual candidate in this process may be quite limited.

Finally, political parties provide a conduit for public engagement in politics between elections. ${ }^{38}$ One of the recurrent criticisms of representative democracy is that it only permits public involvement at election time. This concern can partly be mitigated by representatives' desire to be re-elected; they will need to justify their actions to their electorate. In one respect this argument is weakened by the presence of parties. If people vote for the party, not the person, the actions of an individual candidate may not be decisive in her re-election, but sometimes the presence of parties will strengthen the connection. The candidate's re-election will often depend on her being the party's candidate, rather than on her personal merits. Her election - and chances of political advancement - will depend on the support of the party. There is, then, pressure on the candidate to accept the party line across a range of issues: When people vote for a candidate, they can normally be sure that the candidate will support the party the majority of the time. Furthermore, citizens can continue to engage with the party even if their local candidate is out of sympathy with the party organization. Parties often provide continuing structures for policy-making and campaigning that members can access directly, structures that do not require their local candidates to act as intermediaries. Party members can sit in policy committees, take part in internal debates, and hold positions within the party, even if their local representative is consistently opposed to the party line. To an extent, these party structures can provide a means for citizens to circumvent their local representatives and engage with national politics directly.

\section{Political parties and populism}

The discussion of political parties in the previous section presented them as playing an intermediary role; occupying a space between citizens and their leaders. As Kenneth Roberts and Jan-Werner Müller have argued, there appears to be a connection to be drawn between weak party systems and the rise of populism. ${ }^{39}$ The absence of a well-functioning party system might contribute to the rise of populism, whilst a decaying party system may become vulnerable to its temptations. When functioning well, political parties are antithetical to populism in three related ways.

First, they enable party members to formulate policy to one side of the party leadership. The leadership plays a big role in policy formation, but as we have seen, within the party there are structures and forums that allow party members to contribute to this process. Leaders are put in a context in which they have to explain and justify their views to party members, and will often have to negotiate within party decision-making structures, making compromises before the final policy is produced.

Second, they create structures that continue to constrain leaders even between elections. The strength of a leader's political power depends, in part, on the support of her party. This is particularly clear in parliamentary systems, where the prime minister depends on the continuing support of representatives for her office. It is also true of presidential systems in which the president needs the support of the legislature if she wishes to push through legislation. More broadly, in well-functioning systems, leaders need the support of the party to help campaign,

\footnotetext{
${ }^{38}$ To different degrees: Alan Ware, Political Parties and Party Systems 150-51 (1996).

${ }^{39}$ See Müller, supra note 4, at 78-80. See generally Kenneth M. Roberts, The Oxford Handbook of Populism: Populism And Political Parties (Cristobal R. Kaltwasser et al. eds., 2017).
} 
organize candidates for seats, and ultimately to win elections. A successful leader will need to keep the support of her party.

These first two elements combine to reduce the dangers of groupthink within government. Functioning parties provide a forum within which leaders are compelled to engage with dissent and, if they wish to be effective in their leadership, make compromises. Given the pathology of populism, discussed in the first part of this paper, the relationship that the populist leader has with her people is subverted when the leader is required to discuss, negotiate, and compromise. Where the party system is functioning well, the populist leader cannot get a purchase on the system; she is compelled to act within deliberative structures. Furthermore, the cultish aspect of populist leaders may be premised on their apparent capacity to make the right decision without consultation: they present themselves as having a special capacity to understand the wishes and needs of their people. If populists do tend to depict themselves as messianic figures, compelling a potentially populist leader to compromise may, in itself, help dispel this illusion; they are shown to be like other leaders, reliant on compromise for effective action.

Finally, and more obviously, the existence of a range of vibrant political parties entails that there is always an alternative to the populist leader - whilst, on the other hand, the absence of effective political parties may encourage the growth of personality-based politics. ${ }^{40}$ In the first part of this paper, one of the secondary characteristics of the populist leader was identified as a tendency to claim that they, and only they, represented the "real" people of the state; that the people spoke with a single voice, and that the leader was uniquely able to hear what they were saying. Such a claim is harder to maintain when there is a plurality of parties-harder still to maintain when the value of these parties is explicitly endorsed by the constitution, a point we will return to below.

One reply to the arguments that link the decline of parties to the rise of populism would point to the role that can be played by political parties in facilitating populism. After all, leaders must come from somewhere, and many populist leaders have risen to power through parties, with the party campaigning on the leader's behalf. ${ }^{41}$ Indeed, we sometimes talk of "populist parties" standing behind populist leaders. Populist parties are not a contradiction in terms. On the account of populism developed in this paper, a populist party is one that is centered, or has come to be centered, on the support of a particular individual. ${ }^{42}$ Populist parties can either rise with the populist leader, or they can be the decayed shells of formerly well-functioning parties. ${ }^{43}$ In contrast to a properly functioning political party, the populist party is little more than a personality cult. The populist leader treats political parties - even those that have helped her gain power - like other constitutional institutions. Their existence as a matter of form may play a part in the populist constitution, but their substance is eroded. The populist party, where it exists, is a radically deviant instance of a political party, one which is failing to fulfill its function in the constitution.

\section{Conclusion: guarding against populism}

Populism has become a well-studied topic in academia, an interest that reflects the rise in states that are either dominated by populist leaders or by leaders who exhibit populist tendencies. Whilst diagnosis of the problem is tricky, far harder still is the identification of a cure. There is a wide range of possible steps that could be taken to prevent the emergence of populist leaders. This paper has focused on the role of political parties as a defense against populism. Populism is less likely to

\footnotetext{
${ }^{40}$ See Cindy Skach, The Oxford Handbook of Comparative Constitutional Law: Political Parties and the Constitution 880-81 (Michel Rosenfeld \& Andras Sajó eds., 2012).

${ }^{41}$ See Cas Mudde \& Cristobal R. Kaltwasser, Populism: A Very Short Introduction 51-52 (2017).

${ }^{42}$ See id. at 43-45; see also Yilmaz \& Bashirov, supra note 2, at 2-3.

${ }^{43}$ See Steven Levitsky \& Daniel Ziblatt, How Democracies Die 53-71 (2018) (arguing that it was failures within the Republican Party structures that allowed Trump to gain the presidency).
} 
emerge when political parties are functioning well; that is, when parties are engaging with the electorate and providing a catalyst for the formation of policy. The first step against populism may be as simple as this: Learning to love political parties.

As we have seen, there is a significant amount of criticism of political parties in constitutional scholarship. It is a brand of criticism that populists might welcome, resting as it does on the assertion that by standing in between voters and their rulers, political parties act as an obstacle to the functioning of democracy. ${ }^{44}$ Against this view, the account of political parties developed in this article presents them as playing an essential role within the democratic process, one of the mediating structures of the constitution that makes democratic government possible. Shifting the way we think of politics, recognizing it as a team sport rather than an individual event, may, in itself, blunt the populist challenge. We should celebrate, rather than regret, the presence of contesting views for the direction of the state and rival sets of potential leaders. This plurality is not an example of weakness - a failure to reach agreement-but of strength; the capacity of the constitutional order to contain multiple views of the future of the state. ${ }^{45}$ In the United Kingdom, and elsewhere, the largest opposition party is often styled "Her Majesty's Loyal Opposition." In a valuable recent paper, Grégoire Webber argues that this longstanding idea of loyalty relates to the manner in which the opposition party is regarded by the government: They are constitutionally required to view the opposition party as a legitimate part of the constitutional process, not as a party which is opposed to the interests of the state. ${ }^{46}$ Perhaps the most important aspect of having an official opposition is the public, constitutional, recognition of the legitimacy of party rivalry and dissent. It is a standing reminder of the value of the multiplicity of views about the government of the state. Indeed, in How Democracies Die, Steven Levitsky and Daniel Ziblatt underscore this observation: Key to America's success as a democracy is the unwritten rule that political rivals are treated as legitimate competitors for power and not as opponents of the state. ${ }^{47}$

As well as endorsing the validity of multiple parties, the constitution should be structured to enable and support these institutions. At a minimum, the constitution should be structured such that parties can operate within legislative institutions and are able to exercise control over the executive branch. In a parliamentary system, for example, the prime minister is the member of the legislature who commands the support of the largest number of members of parliament. However this assessment is done, it will require some formal recognition of party structures. Similarly, in a presidential system, there needs to be some mechanism to enable the parties to select candidates for the presidential ballot. More broadly, candidates for election at any level must be able to tell the electorate about their party affiliation. This information needs to be included on the ballot papers found in polling booths.

Beyond this minimal level, the type of support that parties will require depends on local circumstances. In some states political parties can be left, pretty much, to fend for themselves. But there are things that states can do to support parties and help them operate effectively. States can, for example, provide resources to help parties formulate policies. This may be simply a matter of money, providing grants for research, but it can also be through other means. Opposition parties may have discussions with civil servants about the practicalities of implementing policies or may even be involved in discussions with the government about long-term policy objectives. Resources can also be provided to support parties' engagement with their members and with the public at large. The state can subsidize party conferences, offer parties access to public halls to hold meetings, and ensure that all parties have an opportunity to put their messages across during election campaigns.

\footnotetext{
${ }^{44}$ See MÜLLER, supra note 4 , at 75-79.

${ }^{45}$ See Dieter Grimm, Constitutionalism: Past, Present, and Future 143-60 (Martin Loughlin et al. eds., 2016).

${ }^{46}$ See Gregoire Webber, Loyal Opposition and the Political Constitution, 37 Oxford J. LEGAL STUD. 357, 366-69 (2017).

${ }^{47}$ See LEVITSKY \& ZiblatT, supra note 43 , at 212-13.
} 
State support for political parties brings with it a hazard. Whilst there are advantages to such support-and sometimes such support may be necessary to ensure the successful functioning of parties - this support should not prevent the emergence of new political parties or inhibit existing political parties from shifting their ideological outlooks. There is a risk that political parties can become too comfortable; that they cease to engage with the voters who should constitute their base. One of the dangers faced by democratic systems is that their parties ossify and decay from within, becoming shells of their former selves. Parties that were founded in the distant past continue to dominate political life, but gradually become less connected to the citizenry. If new parties are able to enter the political arena, it creates an incentive for the existing parties to adapt- to occupy the ground that might otherwise be taken by these incomers-and also opens up the possibility of the new party replacing its older counterparts. It is extremely hard for a new party to gain traction in any electoral system, but, at the very least, it is possible to avoid insurmountable barriers to entry. So, for example, rules that make it difficult for elected representatives to split from their old party whilst in the legislature might impede the emergence of a new party. Or an electoral system that permits only electors to vote for parties, not individuals, might make it all but impossible for challenges to be made to the existing party structure.

A final way in which states can support parties is through the regionalization of democratic power. There are a great many good arguments for the regionalization of power, but amongst these is the support it gives to political parties that are not, at present, in power at the national level. Having multiple democratic levels permits different parties to exercise power at different levels of the state. The exercise of power may make these parties more attractive to voters: The party is able to achieve, and is seen to achieve, some of its policy objectives. It could be that the regionalization of democratic power helps alleviate a possible danger of electoral systems, such as the United Kingdom's, that are based on first past the post voting; "plurality systems" in the language of those who study elections. Maurice Duverger famously argued that such systems push voters towards a binary choice. ${ }^{48}$ In such a system smaller parties see their electoral support decrease as voters move to parties with a chance of gaining power; this process becomes selfreinforcing, as the weaker the parties become, the more voters decide to abandon them, and the system is pushed towards two, giant, parties. The regionalization of power may make it rational for voters to continue to support other parties in local assemblies - the bifurcation at the national level need not be replicated at the local level—and, moreover, it could be that success at the local level will lead to voters supporting these regional parties in national elections. It is, perhaps, unsurprising that one of the principal political beneficiaries of devolution in the United Kingdom has been the Scottish National Party. Not only has this party enjoyed substantial success in Scottish elections, it has also seen a dramatic increase in its representation in Westminster.

Populist systems, in contrast to straight-forward tyrannies, maintain the trappings of democratic states. Political parties often continue to exist, even after the rise of populism, though in an attenuated form. Whilst, as this paper has argued, political parties are unable to play their full constitutional role in a populist system, they may still have some influence on the policies of the state. Some populist states co-opt political parties-even those nominally opposed to the leadership -into the governance of the state. ${ }^{49}$ These parties are permitted to exist and, sometimes, given some input into the exercise of state power. In part, this might be to provide the populist leader with a semi-independent source of information about the state of her country, ${ }^{50}$ but it also enables the leader to corral dissent. ${ }^{51}$ Given that democratic structures continue to function in

\footnotetext{
${ }^{48}$ See Gary W. Cox, Making Votes Count: Strategic Coordination in the World's Electoral Systems 13-36 (James E. Alt \& Douglass C. North eds., 1997).

${ }^{49}$ See generally Paul Schuler \& Edmund J. Malesky, The OXford Handbook OF Legislative Studies: Authoritarian LEGISLATURES (Shane Martin et al. eds., 2014).

${ }^{50} \mathrm{See} i d$. at $680-82$.

${ }^{51}$ See id. at 682-86; see also Gerrit Krol, Legislative Performance of the Russian State Duma: The Role of Parliament in an Authoritarian Regime, 33 East Eur. POL. 450, 451-53 (2017).
} 
some form in populist regimes, exercising some level of patronage over opposition parties may help reduce the risks posed by elections to the populist's rule. A consequence of this, though, is that political parties survive, in some form, in populist systems, and retain some autonomy from the leadership. Unless the state slips into tyranny, the potential for a challenge to populist rule from this sector of the constitution remains.

These concluding remarks have not sought to provide a complete, or developed, account of the ways states can encourage the flourishing of political parties. Rather, they have sought to sketch out a few of the ways a constitution can be structured to this end and, in so doing, can be structured to reduce the risks of populism. Having a constitution that supports political parties combats populism in two ways. First, well-functioning parties prevent the emergence of populist leaders by acting as mediating institutions linking the leaders of the state to their people, compelling those leaders to defend and negotiate their policies. Second, constitutional support for political parties amounts to a constitutional rejection of populism. It is a recognition of the value of compromise within the government of the state and, moreover, is a recognition of the value of a diversity of views about the direction of the state. The populist leader's claim that she, and only she, can speak for the people may be harder to maintain in a state that is premised on plurality rather than unity.

Cite this article: Barber NW (2019). Populist leaders and political parties. German Law Journal 20, 129-140. https://doi.org/ $10.1017 /$ glj.2019.9 